\title{
Soil Microbial Community Composition in Four Nothotsuga longibracteata Forests in Southern China
}

\author{
Shihong Xiao, ${ }^{1,2}$, Zhongrui Zhang², Weibin You', Jinshan Liu ${ }^{3}$, Jianqin $\mathbf{W u}^{3}$, \\ Changtang Cai ${ }^{3}$, Liyun $\mathrm{Wu}^{1}$, Zhirong $\mathrm{Ji}^{1}$, Dongjin $\mathrm{He}^{{ }^{*}}$ \\ ${ }^{1}$ College of Forestry, Fujian Agriculture and Forestry University, Fuzhou 350002, Fujian Province, China \\ ${ }^{2}$ Guangdong Provincial Key Laboratory of Silviculture, Protection and Utilization/Guangdong Academy of Forestry, \\ Guangzhou 510520, Guangdong Province, China \\ ${ }^{3}$ The Management Authority of Tianbaoyan National Nature Reserve, Yong'an 366032, Fujian Province, China
}

Received: 22 April 2017

Accepted: 27 July 2017

\begin{abstract}
Soil microbial communities play a vital role in soil carbon and carbon sequestration in forest ecosystems. In this study, soils were sampled in Tianbaoyan National Nature Reserve in southeastern China from four Nothotsuga longibracteata forests, including a pure $N$. longibracteata forest (NF), $N$. longibracteata + hardwood mixed forest (NHF), N. longibracteata + Rhododendron simiarum mixed forest (NRF), and N. longibracteata + Phyllostachys pubescens mixed forest (NPF). Our objective was to precisely quantify soil physicochemical properties, microbial biomass, microbial communities, and to evaluate their interrelationships. We used biochemical measurements, a fumigation-extraction method, and phospholipid fatty acid (PLFA) analysis method to show that - except for $\mathrm{pH}$ and soil bulk density (SBD) - soil physicochemical properties differed markedly among the forest types. Microbial biomass carbon $(\mathrm{MBC})$ and nitrogen $(\mathrm{MBN})$ were highest in NHF soils, while the ratio of microbial biomass carbon to nitrogen (MBC:MBN) was highest in NRF and NPF soils. Moreover, the microbial communities of the four forest types exhibited distinct profiles: the highest total PLFA content and content of Grampositive bacteria $(\operatorname{Gram}(+))$, Gram-negative bacteria(Gram(-)), and fungi were found in NRF. Additionally, NHF soil exhibited the highest actinomycetes content, while the highest protozoal content was found in NF soil. The analysis of individual PLFAs using principal component analysis (PCA) demonstrated a clear association of distinct soil PFLA characteristics for each forest type. In conclusion, the soil microbial community structure can be significantly influenced by changes in soil organic carbon (SOC) and MBN. Comparing soil microbial properties in different $N$. longibracteata forests can help us understand the influence of forest types on the structure of microbiota within a system.
\end{abstract}

Keywords: Nothotsuga longibracteata forest, microbial community, phospholipids fatty acid, soil physicochemical properties, Tianbaoyan National Nature Reserve

*e-mail: fjhdj1009@126.com 


\section{Introduction}

Nothotsuga longibracteata (W. C. Cheng) Hu ex C.N. Page is a relic coniferous species endemic to China. It originated in the Tertiary Period and belongs to the genus Nothotsuga in the family Pinaceae. It is considered an excellent species for use in reforestation as it mitigates erosion to permit forest succession, and maintains balance and stability in forest ecosystems. Furthermore, it is also an economically important tree in China [1]. Most native $N$. longibracteata populations are currently concentrated in several highly isolated and fragmented mountain areas of subtropical China, including the Daiyun Mountains in Fujian Province and the Nanling Mountains in the cross-border region of Hunan, Guizhou, Guangxi, Guangdong, and Jiangxi provinces [2]. Owing to climatic and environmental changes, increasing anthropogenic disturbances, and habitat fragmentation over the past several decades, natural $N$. longibracteata populations have severely declined. $N$. longibracteata is currently categorized as "near threatened" on the International Union for Conservation of Nature (IUCN) Red List [3]. Moreover, growth rates of $N$. longibracteata are thought to be very slow and previous studies have shown that poor natural regeneration is a critical problem for the long-term protection and restoration of $N$. longibracteata forests [1]. Therefore, understanding the causes underlying soil quality changes is important for sustainable $N$. longibracteata forest management and restoration. Due to its importance as a desirable tree for afforestation in China, a number of studies have been conducted focusing on soil fertility, soil physicochemical properties, and forest gap studies focusing on characteristics of fallen logs [46]. However, due to the complexity of soil ecosystems and lack of reliable experimental methods, studies of the soil microbial community associated with $N$. longibracteata have not yet been reported.

Soil microbes represent essential participants in carbon sequestration and carbon cycling in forest ecosystems [7-8]. Although they comprise only a small proportion of the total mass of soil organic matter, soil microbial communities play essential roles in regulating soil nutrients and ecosystem functions that are critical for plant growth and maintenance [9-10]. Because soil microorganisms are very sensitive to their environment, changes in soil composition result in rapid alterations in soil microbial species [11]. Owing to their value for ecosystem functional assessment, soil microbial indices have been used for monitoring soil quality [12]. Some research has shown that the distribution of soil microorganisms is closely associated with soil environmental conditions, soil physicochemical factors, plant communities, and other factors that all change during ecosystem development [13-14]. Soil microbes possess cell membranes composed mainly of phospholipids [15]. Composition of the membrane PLFA (fatty acid methyl esters) can be analyzed once esterified and methylated, providing both a quantitative and qualitative profile of the entire microbial composition existing within a soil sample [16]. Therefore, quantitative profiling of soil microbial community composition using PLFA analysis is a sound approach for detecting soil organisms such as bacterial, fungal, and actinomycetes microbes, thereby providing a microbial community fingerprint [17].

Tianbaoyan National Nature Reserve was established in 2003 to protect its virgin forest communities. A $N$. longibracteata natural forest is one of the protected areas in the reserve. Thus it should be appropriate for the study of soil microbial ecology and its relationship to $N$. longibracteata forest ecology. The goal of this study is to better understand carbon and nutrient fluxes in middle subtropical ecosystems within Tianbaoyan National Nature Reserve. The aims of this study are as follows:

1) To analyze the soil microbial communities in four distinct $N$. longibracteata forest types.

2) To elucidate correlations between microbial communities and specific soil properties, i.e., soil $\mathrm{pH}$, bulk density, water content, organic carbon, and total nitrogen.

\section{Materials and Methods}

\section{Site Description}

All research sites were located in Tianbaoyan National Nature Reserve (extending from 25 $50^{\prime} 51^{\prime \prime}$ to $26^{\circ} 01^{\prime} 20^{\prime \prime} \mathrm{N}$, $117^{\circ} 28^{\prime} 03^{\prime \prime}$ to $117^{\circ} 35^{\prime} 28^{\prime \prime} \mathrm{E}$ ), which was established in
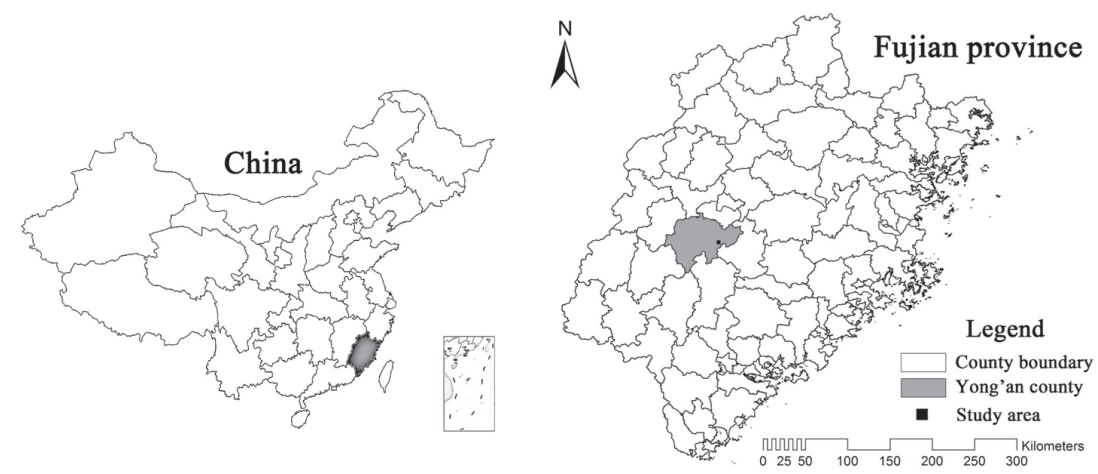

Fig. 1. Geographic location of Tianbaoyan National Nature Reserve. 
2003 in Yong'an City, Fujian Province in southeastern China (Fig. 1). The altitudinal gradient of Tianbaoyan National Nature Reserve varies between $580 \mathrm{~m}$ and 1,604 $\mathrm{m}$ and is within the Daiyun Mountain Range. This area possesses a subtropical oceanic monsoon climate with an annual mean precipitation of 2,039 $\mathrm{mm}$ (peaking in May to September), an annual mean temperature of $15^{\circ} \mathrm{C}$, and an annual relative humidity of more than $80 \%$. The annual average frost-free period is 290 days. This area exhibits distinct seasons and possesses a generally moist and warm climate where water, heat, and light conditions are sufficient for forest growth [1]. Species diversity is abundant in the reserve, which is characterized by a large number of natural $N$. longibracteata, Rhododendron simiarum, and Cryptomeria japonica forests. All of these forest community types possess high conservation value.

\section{Sampling Collection and Experiment Design}

All soil samples were collected from Tianbaoyan National Nature Reserve in October 2015 from a depth of 0-20 cm within the topsoil layer. The pure $N$. longibracteata forest (NF), $N$. longibracteata + hardwood mixed forest (NHF), N. longibracteata $+R$. simiarum mixed forest (NRF), and $N$. longibracteata + Phyllostachys pubescens mixed forest (NPF) were selected as sampling sites. There is little anthropogenic activity in NF, NHF, and NRF, while NPF is impacted by human activities, including weeding, fertilization, and deforestation. Three $20 \times 30$ $\mathrm{m}$ plots located within each $N$. longibracteata forest site, spaced at intervals $20 \mathrm{~m}$ apart, were established in 2009 for field measurements and were selected due to their common features of altitude, slope, slope position, and slope aspect. The environmental characteristics of the four forest types are listed in Table 1. Ten random soil samples were collected by soil cores $(3.5 \mathrm{~cm}$ diameter) from each plot and combined into one composition sample. The composition soil samples were sieved (2 mm) to remove the visible roots, stones, and animals. Then they were divided into two subsamples. One subsample was used to assess physicochemical properties and the other was used to determine microbial biomass and microbial community structure by the composition of PLFA analyses. The subsamples for measuring physicochemical properties were air-dried later and put through a $0.25 \mathrm{~mm}$ sieve. The subsamples for microbial biomass and PLFA analysis were stored at $4^{\circ} \mathrm{C}$. Additionally, soil bulk density (SBD) samples were collected from the top $20 \mathrm{~cm}$ with cutting ring-shaped samples (initial volume $100 \mathrm{~cm}^{3}$, inner diameter $5 \mathrm{~cm}$ ).

\section{Measurement of Soil Physicochemical Properties}

Using a digital $\mathrm{pH}$ meter, measurements of soil $\mathrm{pH}$ were performed using extracts of air-dried samples suspended in water in a 1:2.5 (w/v) soil:water suspension. SBD samples were dried in an oven at $105^{\circ} \mathrm{C}$ for $24 \mathrm{~h}$ to constant weight. SBD values $\left(\mathrm{g} / \mathrm{cm}^{3}\right)$ were calculated from the equation: (dry mass of the sampler (g) - mass of the cylinder sampler $(\mathrm{g})$ )/volume of the cylinder sampler $\left(\mathrm{cm}^{3}\right)$. Soil water content (SWC) was determined gravimetrically after oven-drying soil samples at $105^{\circ} \mathrm{C}$ overnight until no change in mass was observed; water (\%) by mass was calculated as [(wet mass (g) - dry mass $(\mathrm{g})$ )/ wet mass $(\mathrm{g})] \times 100$. Soil organic carbon $(\mathrm{SOC})$ and total soil nitrogen (TN) were detected using a MAX $\mathrm{CN}$ Elemental Analyzer (Elementar Inc., Germany). Total soil phosphorus (TP) was calculated using the molybdenum blue colorimetric method using a UV/visible spectrophotometer after digestion in $\mathrm{H}_{2} \mathrm{SO}_{4}-\mathrm{HClO}_{4}$. Soil microbial biomass carbon (MBC) and nitrogen (MBN) were measured using the fumigation extraction method described by Vance et al. [18], in which the carbon and nitrogen concentrations of non-fumigated soil samples served as estimates for dissolved organic carbon (DOC) and nitrogen (DON), respectively. Briefly, $10 \mathrm{~g}$ (wet weight equivalent) of soil samples were fumigated with ethanol-free $\mathrm{CH}_{3} \mathrm{Cl}$ for $24 \mathrm{~h}$ in vacuum desiccators and non-fumigated soil samples served as controls. The soil samples were extracted with $40 \mathrm{~mL} 0.5 \mathrm{M} \mathrm{K}_{2} \mathrm{SO}_{4}$ for 30 min using a reciprocal shaker. The extracts were filtered through $0.45 \mu \mathrm{m}$ filters and analyzed using a TOC analyzer (TOC-L CPH Analyzer, Shimadzu Inc., Japan). $\mathrm{MBC}$ and $\mathrm{MBN}$ were calculated as the extractable organic carbon and organic nitrogen contents between fumigated and non-fumigated samples using 0.38 [19] and 0.45 [20] as correction factors of respectively.

Table 1. Environmental characteristics of different Nothotsuga longibracteata forests.

\begin{tabular}{|c|c|c|c|c|c|c|c|c|}
\hline $\begin{array}{c}\text { Forest } \\
\text { types }\end{array}$ & Longitude & Latitude & Altitude $(\mathrm{m})$ & Slope aspect & Slope $\left(^{\circ}\right)$ & $\begin{array}{c}\text { Canopy } \\
\text { density }\end{array}$ & ADBH $(\mathrm{cm})$ & ATH $(\mathrm{m})$ \\
\hline $\mathrm{NF}$ & $117^{\circ} 33^{\prime} 09^{\prime \prime} \mathrm{E}$ & $25^{\circ} 55^{\prime} 25^{\prime \prime} \mathrm{N}$ & $1,450 \sim 1550$ & WN10 & 10 & 0.85 & 12.7 & 8.9 \\
\hline $\mathrm{NHF}$ & $117^{\circ} 32^{\prime} 58^{\prime \prime} \mathrm{E}$ & $25^{\circ} 55^{\prime} 22^{\prime \prime} \mathrm{N}$ & $1,350 \sim 1450$ & $\mathrm{EN} 20^{\circ}$ & 15 & 0.90 & 21.6 & 13.8 \\
\hline $\mathrm{NRF}$ & $117^{\circ} 32^{\prime} 54^{\prime \prime} \mathrm{E}$ & $25^{\circ} 55^{\prime} 30^{\prime \prime} \mathrm{N}$ & $1,250 \sim 1350$ & $\mathrm{ES} 30^{\circ}$ & 25 & 0.90 & 19.3 & 10.9 \\
\hline $\mathrm{NPF}$ & $117^{\circ} 32^{\prime} 22^{\prime \prime} \mathrm{E}$ & $25^{\circ} 55^{\prime} 22^{\prime \prime} \mathrm{N}$ & $1,150 \sim 1250$ & $\mathrm{WN} 30^{\circ}$ & 15 & 0.85 & 15.6 & 10.2 \\
\hline
\end{tabular}

$N F$ pure Nothotsuga longibracteata forest; NHF N. longibracteata + hardwood mixed forest; NRF N. longibracteata + Rhododendron simiarum mixed forest; NPF N. longibracteata forest + Phyllostachys pubescens mixed forest; $A D B H$ average diameter at breast height; $A T H$ average tree height 


\section{Determining PLFA}

The extraction and derivatization of PLFAs were conducted following the method of Denef et al. [21]. Briefly, $4 \mathrm{~g}$ (wet weight) of each soil sample was extracted by adding $15 \mathrm{~mL} 0.2 \mathrm{M}$ methanolic $\mathrm{KOH}$ and incubated at $37^{\circ} \mathrm{C}$ for $1 \mathrm{~h}$ in a water bath to form fatty acid methyl esters (FAMEs). FAMEs were extracted with $3 \mathrm{~mL} 1 \mathrm{M}$ acetic acid and $10 \mathrm{~mL}$ hexane. Samples were centrifuged at 2,000 rpm for $15 \mathrm{~min}$ and allowed to stand and separate. The supernatant fractions were evaporated using nitrogen. Each sample was dissolved in $1 \mathrm{~mL}$ hexane. Next, $10 \mu \mathrm{L}$ of a $1 \mathrm{mg} / \mathrm{mL}$ solution of nonadecanoic acid methyl ester (C19:0) as the internal standard added. FAMEs were identified and quantified using a 450-GC/MS system (Varian, Inc., USA) equipped with a capillary column, CP8944 (30 m, $0.25 \mathrm{~mm}$ I.D., $0.25 \mu \mathrm{m}$ film thickness) (Varian, Inc., USA) [22]. The abundances of individual fatty acids were determined and expressed as nmol/g of dry soil after reference to internal standard peak areas of known concentration.

Several branched and saturated PLFAs (i12:0, a13:0, i14:0, a15:0, i16:0, a17:0, i18:0, and i19:0) served as Gram-positive bacterial biomarkers $(\operatorname{Gram}(+))$, while monoenoic and unsaturated and cyclopropane PLFAs

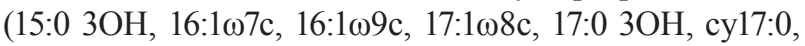
$18: 1 \omega 7 \mathrm{c}$, and cy19:0) were chosen to represent Gramnegative bacterial indicators (Gram(-)). PLFAs 18:1 $\omega 9 \mathrm{c}$, $18: 2 \omega 6,9$, and 18:3 $\omega 3,6,9$ represented fungal biomarkers. The methyl-substituted PLFAs 9Me 15:0, 10Me 18:0, and 10Me 19:0 were employed as actinomycete biomarkers and PLFA 20:4 $\omega 6,9,12,15$ was utilized as a protozoal biomarker. Straight-chain PLFAs, including 12:0, 13:0, 14:0, 15:0, 16:0, 18:0, 19:0, and 20:0, were used as nonspecific bacterial biomarkers [23-25]. All of the PLFAs mentioned above were used to calculate the total PLFAs of each soil microbial community. Total bacterial PLFA content was estimated as the sum of Gram-positive, Gram-negative, and non-specific bacteria. The ratios of Gram(+)-to-Gram(-) PLFAs (Gram(+)/Gram(-)) and fungal-to-bacterial PLFAs (designated F/B and including both $\operatorname{Gram}(+)$ and Gram(-)) were also used as indicators of soil microbial community structure. A ratio of the sum of cyclopropyl fatty acids (cy17:0, cy19:0) to the sum of monoenoic precursors $(16: 1 \omega 7 \mathrm{c}, 18: 1 \omega 7 \mathrm{c})$ (designated cy/ pre) was used as an indicator of physiological stress in the relative abundance of the two microbial groups [26].

\section{Statistical Analysis}

One-way analysis of variance (ANOVA) was used to test the significance of differences among soil samples that were analyzed using least significant difference (LSD) tests at the $P<0.05$ level by SPSS Version 21.0 for Windows (SPSS Inc., Chicago, USA). Principal components analysis (PCA) was conducted on the microbial community compositions of the four $N$. longibracteata forests based on PLFA biomarkers content of the entire PLFAs profile using CANOCO 5.0 for
Windows (Ithaca, NY, USA). All data were averages of three replicates. Redundancy Analysis (RDA) was used to test specific hypotheses about the relationship between soil properties ( $\mathrm{pH}, \mathrm{SBD}, \mathrm{SWC}, \mathrm{SOC}, \mathrm{TN}$, TP, TK, C:N, C:P, DOC, DON, MBC and MBN) and microbial community composition (all the individual PLFA biomarkers) were expressed as an ordination plot. Soil properties were tested for their significance as contributing factors to the observed variation in the PLFA data by the Monte Carlo permutation test $(P<0.05)$.

\section{Results}

\section{Soil Physicochemical Properties}

Soil $\mathrm{pH}$ values varied from 4.30 to 5.20 , indicating that all test samples were acidic. Soil bulk density was highest in NRF $\left(1.29 \mathrm{~g} / \mathrm{cm}^{3}\right)$, followed by NF $\left(1.19 \mathrm{~g} / \mathrm{cm}^{3}\right), \operatorname{NHF}\left(1.03 \mathrm{~g} / \mathrm{cm}^{3}\right)$, and NPF $\left(1.01 \mathrm{~g} / \mathrm{cm}^{3}\right)$. Soil water content values were $20.80 \%, 21.25 \%, 16.33 \%$, and $15.00 \%$ for NF, NHF, NRF, and NPF, respectively. Both soil organic carbon content and total soil nitrogen were significantly highest for NHF. Total soil phosphorus in NRF was significantly lower than for NF, NHF, and NPF. Both $\mathrm{C}: \mathrm{N}$ and $\mathrm{C}: \mathrm{P}$ ratios exhibited their lowest values for NF. Soil-dissolved organic carbon was significantly higher in NF than for NHF, NRF, and NPF. Soil-dissolved organic nitrogen content ranged from $36.53 \mathrm{mg} / \mathrm{kg}$ for NRF to $97.64 \mathrm{mg} / \mathrm{kg}^{1}$ for NHF (Table 2).

\section{Soil Microbial Properties}

Soil MBC, MBN, and the MBC:MBN ratio differed significantly among forest types (Figs 2a-c). Both soil $\mathrm{MBC}$ and $\mathrm{MBN}$ showed the following trend: $\mathrm{NHF}>\mathrm{NF}>\mathrm{NPF}>\mathrm{NRF}$ (Figs 2a-b), while the MBC:MBN ratios for NRF and NPF were significantly higher than ratios for NF and NHF (Fig. 2c). Most soil MBC and MBN values in this study varied significantly between soil samples of the four forest types $(P<0.05)$.

In total, 31 different PLFA biomarkers were detected among all of the soil samples. Soil total PLFAs, Grampositive PLFAs, Gram-negative PLFAs, fungal PLFAs, actinomycetes PLFAs, and protozoal PLFAs significantly differed among the four forest types (Figs 3a-f). Total PLFAs, Gram-positive PLFAs, Gram-negative PLFAs, and fungal PLFAs were significantly higher in NRF than in other forests (Figs 3a-d). NHF exhibited the highest actinomycetes PLFA content, while NPF exhibited the lowest actinomycetes PLFAs content (Fig. 3e). NF exhibited higher protozoal PLFAs than did NHF, NPF, and NRF (Fig. 3f).

Fig. 3 shows that the Gram(+)/Gram(-), F/B, and cy/ pre ratios of soils in four different $N$. longibracteata forests also differed significantly (Figs 4a-c). The highest Gram(+)/Gram(-) PLFAs ratio occurred in NRF and this value was significantly greater than for the other forests (Fig. 4a). The F/B ratio was also significantly higher in 
Table 2. Soil physicochemical properties in different Nothotsuga longibracteata forests.

\begin{tabular}{|c|c|c|c|c|}
\hline & NF & NHF & NRF & NPF \\
\hline $\mathrm{pH}$ & $4.30 \pm 0.39 \mathrm{a}$ & $4.61 \pm 0.28 \mathrm{a}$ & $4.33 \pm 0.27 \mathrm{a}$ & $5.20 \pm 0.75 \mathrm{a}$ \\
\hline $\mathrm{SBD}\left(\mathrm{g} / \mathrm{cm}^{3}\right)$ & $1.19 \pm 0.10 \mathrm{a}$ & $1.03 \pm 0.10 \mathrm{a}$ & $1.29 \pm 0.16 \mathrm{a}$ & $1.01 \pm 0.06 \mathrm{a}$ \\
\hline $\mathrm{SWC}(\%)$ & $20.80 \pm 1.75 \mathrm{a}$ & $21.25 \pm 2.10 \mathrm{a}$ & $16.33 \pm 2.17 \mathrm{ab}$ & $15.00 \pm 1.39 \mathrm{~b}$ \\
\hline $\mathrm{SOC}(\mathrm{g} / \mathrm{kg})$ & $103.96 \pm 4.20 \mathrm{~b}$ & $172.19 \pm 23.62 \mathrm{a}$ & $80.88 \pm 7.90 \mathrm{~b}$ & $115.49 \pm 5.13 \mathrm{~b}$ \\
\hline $\mathrm{TN}(\mathrm{g} / \mathrm{kg})$ & $2.98 \pm 0.40 \mathrm{~b}$ & $3.67 \pm 0.31 \mathrm{a}$ & $1.70 \pm 0.22 \mathrm{c}$ & $2.52 \pm 0.19 \mathrm{~b}$ \\
\hline $\mathrm{TP}(\mathrm{g} / \mathrm{kg})$ & $0.64 \pm 0.10 \mathrm{a}$ & $0.56 \pm 0.07 \mathrm{ab}$ & $0.35 \pm 0.04 \mathrm{c}$ & $0.47 \pm 0.05 \mathrm{bc}$ \\
\hline $\mathrm{C}: \mathrm{N}$ & $35.37 \pm 3.49 \mathrm{a}$ & $46.92 \pm 5.03 \mathrm{a}$ & $48.76 \pm 10.65 \mathrm{a}$ & $45.45 \pm 3.23 \mathrm{a}$ \\
\hline $\mathrm{C}: \mathrm{P}$ & $165.61 \pm 22.75 \mathrm{~b}$ & $314.58 \pm 73.07 \mathrm{a}$ & $235.28 \pm 20.32 \mathrm{ab}$ & $262.59 \pm 20.11 \mathrm{ab}$ \\
\hline $\mathrm{DOC}(\mathrm{mg} / \mathrm{kg})$ & $756.95 \pm 76.64 \mathrm{a}$ & $586.78 \pm 114.64 \mathrm{~b}$ & $382.30 \pm 36.21 \mathrm{c}$ & $95.29 \pm 11.14 \mathrm{~d}$ \\
\hline $\mathrm{DON}(\mathrm{mg} / \mathrm{kg})$ & $77.35 \pm 8.16 \mathrm{~b}$ & $97.64 \pm 7.81 \mathrm{a}$ & $36.53 \pm 3.88 \mathrm{c}$ & $50.72 \pm 6.46 \mathrm{c}$ \\
\hline
\end{tabular}

$S B D$ soil bulk density; $S W C$ soil water content; $S O C$ soil organic carbon; $T N$ total soil nitrogen; $T P$ total soil phosphorus; $C: N$ the ratio of soil organic carbon to total soil nitrogen; $C: P$ the ratio of soil organic carbon to total soil phosphorus; $D O C$ dissolved organic carbon; $D O N$ dissolved organic nitrogen. Values are mean $\pm \mathrm{SE}(n=3)$. In each row, different lowercase letters indicate statistically significant differences $(P<0.05)$. NF, NHF, NRF, and NPF are the same as in Table 1.

NPF than in the other three forests (Fig. 4b), as illustrated by the values $0.96,1.35,1.59$, and $1.30 \mathrm{nmol} / \mathrm{g}$ for $\mathrm{NF}$,

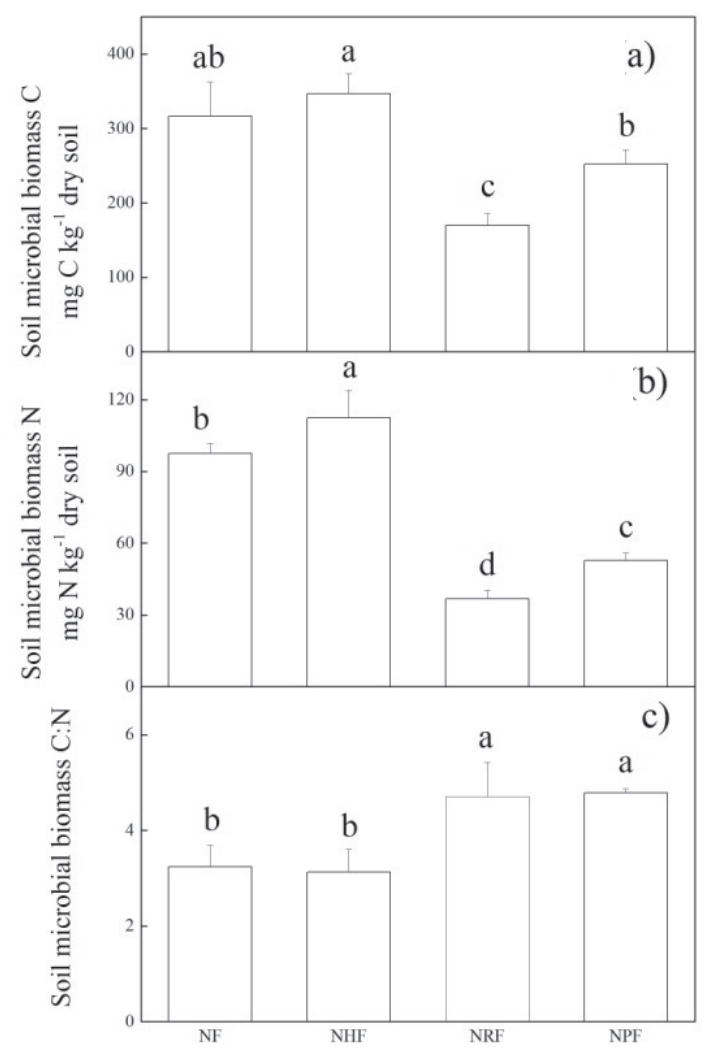

Fig. 2. Soil microbial biomass $\mathrm{C}$ a), $\mathrm{N}$ b), and $\mathrm{C}: \mathrm{N}$ ratio $\mathrm{c}$ ) in four Nothotsuga longibracteata forests. NF, NHF, NRF, and NPF are defined as in Table 1. Bars represent means \pm standard deviations of three replicates. Different lowercase letters above bars indicate significant differences at the $P<0.05$ level among forests.
NHF, NRF, and NPF, respectively. NRF and NF exhibited the highest cy/pre PLFAs ratio, while NHF and NPF exhibited lower cy/pre PLFAs ratios (Fig. 4c).

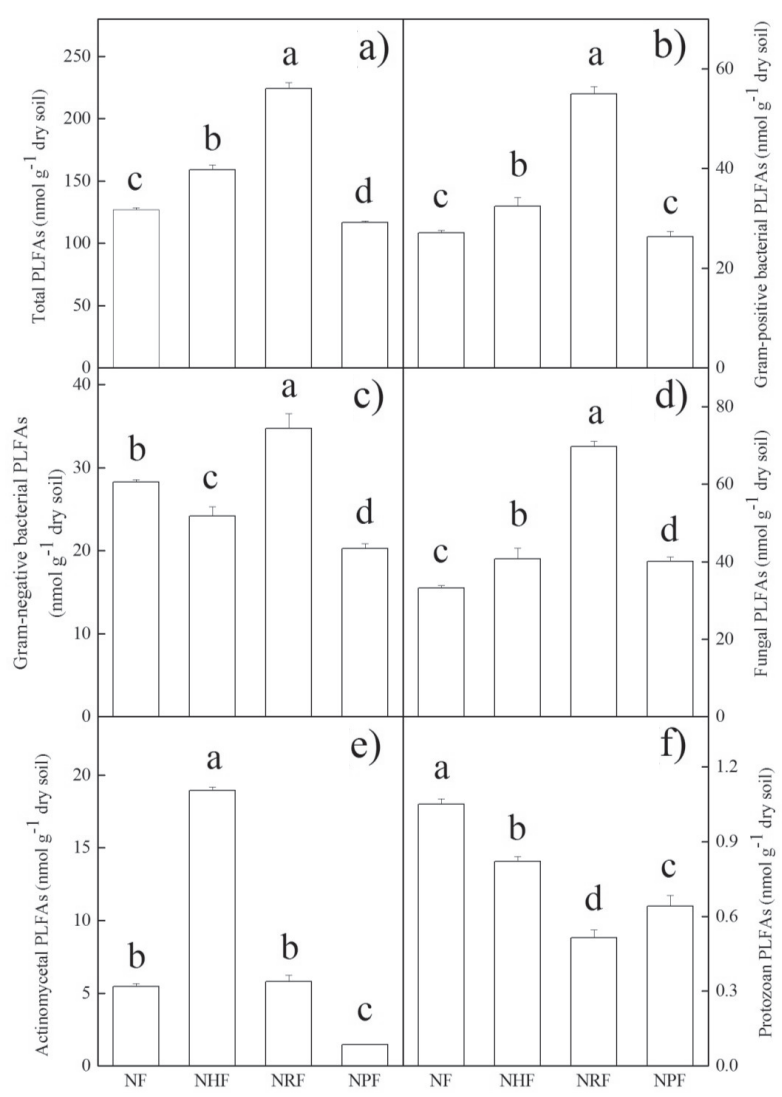

Fig. 3. Total PLFAs a), Gram-positive bacterial PLFAs b), Gramnegative bacterial PLFAs c), fungal PLFAs d), actinomycetes PLFAs e), and protozoal PLFAs f) for four different Nothotsuga longibracteata forests. NF, NHF, NRF, and NPF are defined as in Table 1. 
Individual PLFA content values were subjected to PCA (Fig. 5). The first principal component (PC1) explained $56.18 \%$ of the total variation and the second principal component (PC2) explained 30.76\% (Fig. 5a). We plotted the PC1 and PC2 score values for all analyzed samples, which resulted in a clear segregation between the four forest types (Fig. 5b). The most discriminatory PLFA biomarkers for the positive region of PC1 were several specific bacterial biomarkers (Gram-positive: a17:0, a15:0, i16:0; non-specific: 13:0, 19:0), one fungal biomarker $(18: 2 \omega 6,9)$, and one actinomycetes biomarker (10Me19:0). The most discriminatory PLFA biomarkers, which fell within the positive region of $\mathrm{PC} 2$, were biomarkers of actinomycetes (9Me15:0), non-specific bacteria (16:0), and Gram-negative bacteria (16:167c) (Fig. 4a).

\section{Relationship between Microbial Community Composition and Soil Physicochemical Properties}

The relationships between microbial community composition and soil physicochemical properties were analyzed using RDA. We conducted a forward selection for the variables before conducting RDA. The significance of environmental variables (MBN and SOC) present in the ordination biplot were determined using Monte

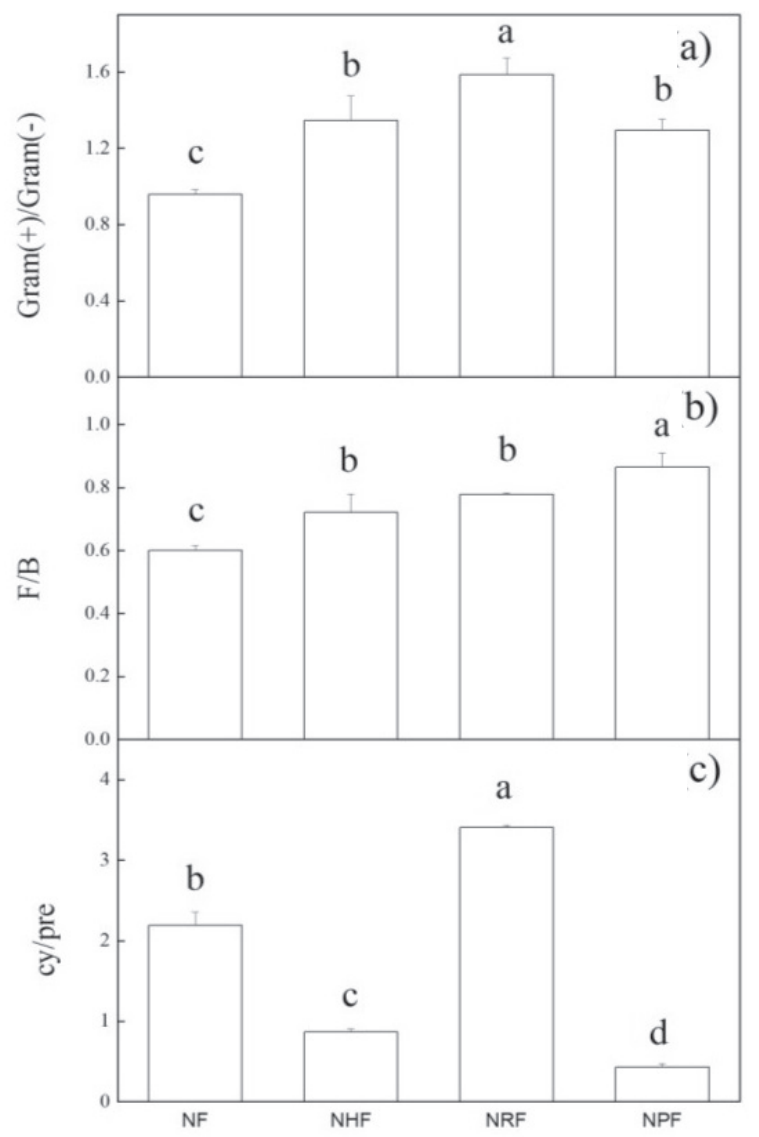

Fig. 4. Soil Gram(+)/Gram(-) PLFAs a), F/B PLFAs b), and cy/ pre PLFAs c) ratios in four different Nothotsuga longibracteata forests. NF, NHF, NRF, and NPF are designated as in Table 1.
Carlo permutation tests $(P<0.05)$. The results showed that the variations in PLFA profiles were most influenced by $\operatorname{MBN}(F=4.30, P=0.006)$ and $\operatorname{SOC}(F=3.50, P=$ $0.048)$. In the RDA biplot, the first and second axis could explain $30.23 \%$ and $19.55 \%$ of the variation, respectively. Changes in microbial community composition along axis 1 were associated with higher values of MBN and lower values of SOC (Fig. 6). The variables MBN and SOC showed a positive association with axis 1 .

\section{Discussion}

Our study indicates that variations in soil microbial communities were significantly associated with SOC and MBN (Fig. 6). These results are supported by previous reports demonstrating that $\mathrm{SOC}$ is the primary $\mathrm{C}$ source
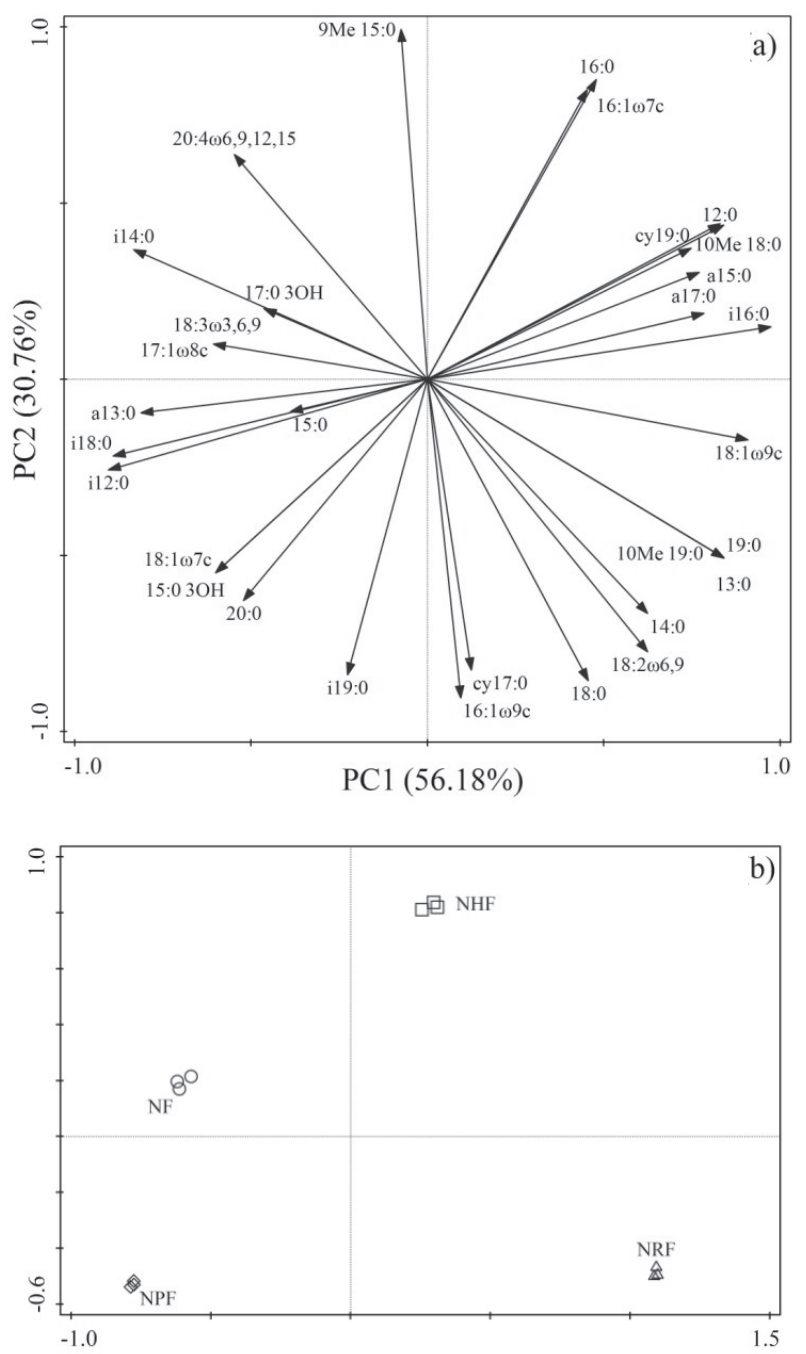

Fig. 5. Results of principal component analysis (PCA): a) the distribution of individual PLFA biomarkers; $b$ ) the distribution of the soil samples in different Nothotsuga longibracteata forests. Vectors represent the mean amount of soil PLFA biomarkers. The direction of an arrow indicates the steepest increase in the variable, and the length indicates relativity to other variables. NF, NHF, NRF, and NPF designations are as in Table 1. 


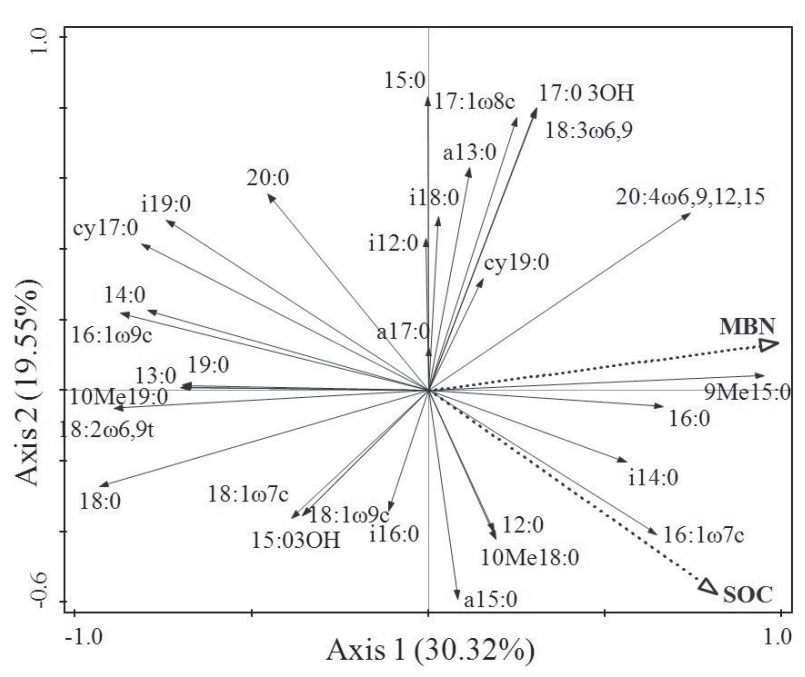

Fig. 6. Redundancy Analysis (RDA) results of microbial community composition and soil physicochemical properties. Vectors represent the mean value of the soil physicochemical properties and the mean PLFA content in the microbial community. The direction of an arrow indicates the steepest increase in the variable, and the length indicates the strength of the relationship of the variable with the other variables. For all RDA plots, values on the $x$ and $y$ axes represent the percentage variation explained by axis 1 and axis 2 , respectively $(P<0.05)$.

maintaining the soil community [27]. Furthermore, other studies have revealed that reduced SOC can lead to decreased microbial biomass and changes in microbial community profiles [28]. Because soil microbial biomass is an effective index for evaluating changes in soil properties and for assessing soil quality and health [29], we also studied this factor. Our results demonstrate that significantly higher MBC and MBN values in NHF and NF soils vs. NPF and NRF soils may be attributed to higher soil organic carbon, as well as higher total $\mathrm{N}$ and P (Fig. 2, Table 2). This result is consistent with some results of previous studies that suggest that the content of soil microbial biomass is closely associated with changes in the content of soil microorganisms and to the growth of vegetation [29-30]. Interestingly, we found markedly higher MBC:MBN ratios in NRF and NPF soils than in NF and NHF soils, and we postulate that the limited $\mathrm{N}$ in NRF and NPF soils might be responsible for this phenomenon (Fig. 2, Table 2).

Using a separate strategy, PLFA and soil physicochemical analyses were also used to demonstrate correlations of forest type with soil microbial community structure. Total amounts of various PLFA markers differed between forest types, revealing that the microbial community biomass profile of a particular forest type could distinguish it from the other three types. These differences were likely apparent due to the large number of Gram-positive bacterial biomarkers, Gram-negative bacterial biomarkers, and fungal biomarkers studied in this work. It is known that soil microbial community composition is affected by plant communities because the quality and quantity of leaf root litter exudates determine the soil organic matter and availability of nutrients to soil microbes [7, 31]. In our study, total PLFAs were low in NPF, whereas SOC was relatively high. We surmised that the growth of the soil microorganism was restricted by the rapid growth of $P$. pubescens, because of phytochemical inhibition and/or nutrient competition [32]. In addition, human activities might inhibit microbial communication.

Of additional note, we found that the Gram $(+) /$ Gram(-) PLFAs ratio was 0.96 in NF, suggesting that Gram-negative bacteria dominated this ecosystem (Fig. 4a). A high percentage of Gram-negative relative to Gram-positive bacteria are usually related to high amounts of saprophytic fungal biomarkers, whereby high total biomass is a characteristic of forest soils because they are rich in complex plant-derived organic matter with low $\mathrm{pH}$ [33-34]. In contrast, a high ratio of Gram-positive relative to Gram-negative bacteria is usually associated with soils low in organic carbon [34]. In the other three forests where the $\operatorname{Gram}(+) / \operatorname{Gram}(-)$ ratio was greater than 1.0 (Fig. 4a), indicating a change from a Gram-negative dominant community to a Gram-positive dominant community might indicate a change from copiotrophic to oligotrophic conditions due to competition between aboveground vegetation and the soil microbes for organic carbon [35].

In order to uncover other factors impacting microbial communities, the fungal-to-bacterial PLFAs ratio has been studied to understand the physiological state of the soil microbial community responsible for soil organic matter accumulation, turnover, and an ecosystem's buffering capacity [29]. This ratio is commonly served as a biomass index to measure the relative abundance of fungi and bacteria within microbial communities [7]. In this study, the F/B ratio in NPF was significantly higher than for the other three forests (Fig. 4b), indicating a higher carbon accumulation and self-buffering capacity of NPF soil.

Some previous studies showed that the ratio of cy/pre has been linked to nutritional stress and $\mathrm{pH}$ [36]. A smaller cy/pre ratio represents less stress of the microbial community (e.g., in terms of the limitation of carbon or oxygen) [29]. In this study, the cy/pre ratio in NPF was significantly lower than in the other three forests, demonstrating that the environmental stress level was relatively low and that the carbon and oxygen contents of soil in NPF were sufficient for the growth of microbes [37]. In NF, NHF, and NRF, the ratio of cy/pre was over 0.5 , which may indicate the existence of serious environmental stress [37].

\section{Conclusions}

We have compared differences between soil microbial communities among four different $N$. longibracteata forest types and explored the factors controlling these variations. Having found that SOC is the predominant factor influencing soil microbes in the 
four $N$. longibracteata forests, we have also demonstrated that soil MBN plays an important role. However, no strong relationship was observed between the microbial community profile and $\mathrm{pH}$ or $\mathrm{C}: \mathrm{N}$ ratio, as had been demonstrated in other studies. However, in this work obvious differences in soil microbial community profiles were demonstrated between different $N$. longibracteata forests. These microbial community differences and the reasons behind them should inform future $N$. longibracteata reforestation efforts.

\section{Acknowledgements}

This study received funding by the National Natural Science Foundation of China (No. 31370624), the Specialized Research Fund for the Doctoral Program of Higher Education (No. 20103515110005), the National Science Foundation of Fujian (No. 2011J01071), and the Young Teacher Project of Fujian Province (No. JK2013016; JA13118). We thank the Management Authority of Tianbaoyan National Nature Reserve for granting permission for this project. We also wish to thank Yunqiang Shen, Liyan Jian, Xu You, and Sixiao Yan for their assistance in soil sampling and data analysis.

\section{References}

1. YOU H.M., HE D.J., YOU W.B., LIU J.S., CAI C.T. Effect of Environmental Gradients on the Quantity and Quality of Fallen Logs in Tsuga longibracteata Forest in Tianbaoyan National Nature Reserve, Fujian Province, China. Journal of Mountain Science. 10, 1118, 2013.

2. QIU Y.J., LIU Y.F., KANG M., YI G.M., HUANG H.W. Spatial and temporal population genetic variation and structure of Nothotsuga longibracteata (Pinaceae), a relic conifer species endemic to subtropical China. Genetics and Molecular Biology. 36, 598, 2013.

3. FARJON A., CHRISTIAN T., ZHANG D. Nothotsuga longibracteata. The IUCN Red List of Threatened Species. Version 2016-1. 2013. <www.iucnredlist.org>. Accessed on 14 August 2016.

4. YOU H.M., HE D.J., CAI C.T., LIU J.S., HONG W., YOU W.B., WANG L., XIAO S.H., HU J., ZHENG X.Y. Assessment on Effect of Fallen Woods on Soil Fertility in Tsuga longibracteata Forest in Tianbaoyan National Nature Reserve. Chinese Journal of Applied and Environmental Biology. 19, 168, 2013 [In Chinese].

5. YOU H.M., HE D.J., LIU J.S., CAI C.T., YOU W.B., XIAO S.H. Effect of covering with fallen logs on soil physicochemical property of Tsuga longibracteata forest in Tianbaoyan National Nature Reserve. Journal of Plant Resources and Environment. 22, 18, 2013 [In Chinese].

6. XIAO S.H., YOU H.M., YOU W.B., LIU J.S., CAI C.T., WU J.Q., JI Z.R., ZHAN S.H., HU Z.S., ZHANG Z.R., HE D.J. Rhizosphere and bulk soil enzyme activities in a Nothotsuga longibracteata, forest in the Tianbaoyan National Nature Reserve, Fujian Province, China. Journal of Forestry Research. 28, 521, 2017.

7. CAO Y.S., FU S.L., ZOU X.M., CAO H.L., SHAO Y.H., ZHOU L.X. Soil microbial community composition under
Eucalyptus plantations of different age in subtropical China. European Journal of Soil Biology. 46, 128, 2010.

8. DRAKE J.E., GALLET-BUDYNEK A., HOFMOCKEL K.S., BERNHARDT E.S., BILLINGS S.A., JACKSON R.B., JOHNSEN K.S., LICHTER J., MCCARTHY H.R., MCCORMACK M.L., MOORE D.J., OREN R., PALMROTH S., PHILLIPS R.P., PIPPEN J.S., PRITCHARD S.G., TRESEDER K.K., SCHLESINGER W.H., DELUCIA E.H., FINZI A.C. Increases in the flux of carbon belowground stimulate nitrogen uptake and sustain the long-term enhancement of forest productivity under elevated $\mathrm{CO}_{2}$. Ecology Letters. 14, 349, 2011.

9. SIMPSON A.J., SIMPSON M.J., SMITH E., KELLEHER B.P. Microbially derived inputs to soil organic matter: Are current estimates too low? Environmental Science and Technology. 41, 8070, 2007.

10. CHAPARRO J.M., SHEFLIN A.M., MANTER D.K., VIVANCO J.M. Manipulating the soil microbiome to increase soil health and plant fertility. Biology and Fertility of Soils. 48, 489, 2012.

11. HU L., XIANG Z.Y., WANG G.X., RAFIQUE R., LIU W., WANG C.T. Changes in soil physicochemical and microbial properties along elevation gradients in two forest soils. Scandinavian Journal of Forest Research. 31, $1,2016$.

12. CHENG F., PENG X.B., ZHAO P., YUAN J., ZHONG C.G., CHENG Y.L., CUI C., ZHANG S.X. Soil microbial biomass, basal respiration and enzyme activity of main forest types in the Qinling Mountains. PLoS One. 8, e67353, 2013.

13. GELSOMINO A., KEIJZER-WOLTERS A.C., CACCO G., VAN ELSAS J.D. Assessment of bacterial community structure in soil by polymerase chain reaction and denaturing gradient gel electrophoresis. Journal of Microbiological Methods. 38, 1, 1999.

14. CAI Y.F., BARBER P., DELL B., O'BRIEN P., WILLIAMS N., BOWEN B., HARDY G. Soil bacterial functional diversity is associated with the decline of Eucalyptus gomphocephala. Forest Ecology and Management. 260, 1047, 2010.

15. FRANCISCO R., STONE D., CREAMER R.E., SOUSA J.P., MORAIS P.V. European scale analysis of phospholipid fatty acid composition of soils to establish operating ranges. Applied Soil Ecology, 97, 49, 2015.

16. PIOTROWSKA-SEGET, MROZIK A. Signature lipid biomarker (SLB) analysis in determining changes in community structure of soil microorganisms. Polish Journal of Environmental Studies. 12, 669, 2003.

17. HEBEL C.L., SMITH J.E., CROMACK K. Invasive plant species and soil microbial response to wildfire burn severity in the Cascade Range of Oregon. Applied Soil Ecology. 42, $150,2009$.

18. VANCE E.D., BROOKES P.C., JENKINSON D.S. An extraction method for measuring soil microbial biomass $\mathrm{C}$. Soil Biology and Biochemistry. 19, 703, 1987.

19. PANDEY C.B., SINGH G.B., SINGH S.K., SINGH R.K. Soil nitrogen and microbial biomass carbon dynamics in native forests and derived agricultural land uses in a humid tropical climate of India. Plant and Soil. 333, 453, 2010.

20. JENKINSON D.S., BROOKES P.C., POWLSON D.S. Measuring soil microbial biomass. Soil Biology and Biochemistry. 36, 5, 2004.

21. DENEF K., BUBENHEIM H., LENHART K., VERMEULEN J., VAN CLEEMPUT O., BOECKX P., MÜLLER C. Community shifts and carbon translocation within metabolically-active rhizosphere microorganisms in 
grasslands under elevated $\mathrm{CO}_{2}$. Biogeosciences Discussions. 4, 769, 2007.

22. WU L.K., LI Z.F., LI J., KHAN M.A., HUANG W.M., ZHANG Z.Y., LIN W.X. Assessment of shifts in microbial community structure and catabolic diversity in response to Rehmannia glutinosa monoculture. Applied Soil Ecology. 67, 1, 2013.

23. KIMURA M., ASAKAWA S. Comparison of community structures of microbiota at main habitats in rice field ecosystems based on phospholipid fatty acid analysis. Biology and Fertility of Soils. 43, 20, 2006.

24. JOHANSEN A., OLSSON S. Using Phospholipid Fatty Acid Technique to Study Short-Term Effects of the Biological Control Agent Pseudomonas fluorescens DR54 on the Microbial Microbiota in Barley Rhizosphere. Microbial Ecology. 49, 272, 2005.

25. HUYGENS D., SCHOUPPE J., ROOBROECK D., ALVAREZ M., BALOCCHI O., VALENZUELA E., PINOCHET D., BOECKX P. Drying-rewetting effects on N cycling in grassland soils of varying microbial community composition and management intensity in south central Chile. Applied Soil Ecology. 48, 270, 2011.

26. ALIASGHARZAD N., MÅRTENSSON L.M., OLSSON P.A. Acidification of a sandy grassland favours bacteria and disfavours fungal saprotrophs as estimated by fatty acid profiling. Soil Biology and Biochemistry. 42, 1058, 2010.

27. CUI H.J., WANG G.X., YANG Y., YANG Y., CHANG R.Y., RAN F. Soil microbial community composition and its driving factors in alpine grasslands along a mountain elevational gradient. Journal of Mountain Science. 13, 1013, 2016.

28. KRAMER C., GLEIXNER G. Soil organic matter in soil depth profiles: Distinct carbon preferences of microbial groups during carbon transformation. Soil Biology and Biochemistry. 40, 425, 2008.

29. HUANG Y.M., LIU D., AN S.S. Effects of slope aspect on soil nitrogen and microbial properties in the Chinese Loess region. Catena. 125, 135, 2015.
30. WEI H., XIAO G.L., GUENET B., JANSSENS I.A., SHEN W.J. Soil microbial community composition does not predominantly determine the variance of heterotrophic soil respiration across four subtropical forests. Scientific Reports. 5, 7854, 2015.

31. ZHOU Y., CLARK M., SU J., XIAO C.W. Litter decomposition and soil microbial community composition in three Korean pine (Pinus koraiensis) forests along an altitudinal gradient. Plant and Soil. 386, 171, 2015.

32. SINGH S., GHOSHAL N., SINGH K.P. Variations in soil microbial biomass and crop roots due to differing resource quality inputs in a tropical dryland agroecosystem. Soil Biology and Biochemistry. 39, 76, 2007.

33. MATHEW R.P., FENG Y.C., GITHINJI L., ANKUMAH R., BALKCOM K.S. Impact of No-Tillage and Conventional Tillage Systems on Soil Microbial Communities. Applied and Environmental Soil Science. 1, 2012.

34. HERMAN D.J., FIRESTONE M.K., NUCCIO E., HODGE A. Interactions between an arbuscular mycorrhizal fungus and a soil microbial community mediating litter decomposition. Fems Microbiology Ecology. 80, 236, 2012.

35. CHEN D.M., ZHOU L.X., WU J.P., HSU J., LIN Y.B., FU S.L. Tree girdling affects the soil microbial community by modifying resource availability in two subtropical plantations. Applied Soil Ecology. 53, 108, 2012.

36. CHANG E.H., CHEN C.T., CHEN T.H., CHIU C.Y. Soil microbial communities and activities in sand dunes of subtropical coastal forests. Applied Soil Ecology, 49, 256, 2011.

37. ALLISON V.J., MICHAEL MILLER R., JASTROW J.D., MATAMALA R., ZAK D.R. Changes in Soil Microbial Community Structure in a Tallgrass Prairie Chronosequence. Soil Science Society of America Journal. 69, 1412, 2005. 